\title{
Khadzhi-Murat's Silence
}

\section{David Herman}

Khadzhi-Murat, Tolstoi's last major fiction, stands alone in his oeuvre in flagrant violation of his late ethical and aesthetic standards-an unprecedentedly dark apprehension of the human condition and a reconceptualization of piety. At its heart are silences-literal, near-, figurative, and implicit-in unspoken critique of all nontrivial language, narrative, moralizing, and teaching. Silence first strikes the reader in the hero's refusal to murmur against God as he dies, but retrospectively turns up everywhere, despite the obvious presence of lots of words: in the peculiar plot that has nothing to say; in the refusal to perform the usual Tolstoian adjudication of the disparate viewpoints depicted; in the hero's childhood reminiscences, hidden from listeners even as the essential in them is hidden from him; in the painful taciturnity of God himself, which, like the other core themes, is purposefully barely mentioned. Khadzhi-Murat's indirection enacts an intuition whose mere assertion would fail, since it is an intuition about assertability itself. Something central has shifted for Tolstoi; now it is through silence and absence - the gaps in the said and the sayable - that the most important truths come to us, hence that is the only truthful way to inscribe them.

\section{Engendering Suspicion: Homosexual Panic in the Post-Soviet Detektiv}

\section{Brian James BaER}

This article examines the workings of the sexual closet within the enormously popular genre of the Russian detektiv, or detective story. Informed by the work of Eve Kosofsky Sedgwick and D. A. Miller, the article focuses on the dramatization of homosexual panic among various male characters in Aleksandra Marinina's Stilist (1996) and Boris Akunin's Koronatsiia (2001) in order to explore the experience of masculine subjectivity in post-Soviet culture. In both novels, a perceived crisis in patriarchal authority unleashes suspicions and anxieties regarding the experience of being and becoming a man, which is defined against the feminine and the homosexual. Figured both as an effect of and as a threat to male-male bonds, homosexual panic testifies to the interiorization of sexual and gender norms, which makes being male a highly self-conscious enterprise and fuels nostalgia for a mythic time before the appearance of homosexuality.

\section{A Visit to the Museum: Aleksandr Sokurov's Russian Ark and the Framing of the Eternal}

TIM Harte

In this close analysis of Aleksandr Sokurov's 2002 film Russkii kovcheg (Russian ark), Tim Harte explores the interplay between the medium of paint- 
ing and cinema in this unprecedented ninety-minute single-shot film set in the grand halls and galleries of the Hermitage Museum. As Harte argues, the film's unique premise and setting allow Sokurov to convey how the museum, its art and history, and subsequently cinema can affirm a nation's culture, transporting the past ever so evocatively into the present in order to sustain culture's vitality. Throughout Sokurov's ninety-minute single-shot fusion of Western art and Russian history, a continual emphasis on the image of the frame prevails, with the frame constituting an important artistic and metaphysical threshold for the filmmaker. Constantly moving through the ubiquitous frames, Sokurov establishes his own cinematic rendering of culture's eternal essence.

\section{National Identity and Public Support for Political and Economic Reform in Ukraine}

\section{STEPHEN SHULMAN}

This article investigates the impact conceptions of national identity have on mass support for political and economic reform in Ukraine. After laying out the theoretical linkage between national identity and models of political and economic development, it uses a 2001 mass public opinion survey to assess the influence of two competing versions of national identity-Eastern Slavic and Ethnic Ukrainian-on reformist attitudes in Ukraine. Bivariate and multivariate statistical analysis demonstrate that an Ethnic Ukrainian national identity is associated with pro-democratic and pro-market orientations, while the Eastern Slavic national identity is associated with antidemocratic and antimarket orientations. Furthermore, the apparent effect of national identity is stronger than that of other factors that scholars have typically argued promote backing for democracy and capitalism in the postcommunist region, including education, age, urban residence, and economic well-being.

\section{Borderlands of Faith: Reconsidering the Origins of a Ukrainian Tragedy}

\section{BARBARA SkINNER}

Critiquing prevalent secular explanations for the cossack-led uprising called Koliivshchyna that erupted in the Ukrainian borderlands of the Polish-Lithuanian Commonwealth in 1768, this article identifies religion as the root cause of the uprising. Traditional nationalist and socioeconomic arguments explain Ukrainian violence against Poles and Jews, but do not account for Ukrainian violence against Ukrainians, which set this uprising apart from previous cossack-led disturbances. Increasing conflict between Uniate and Orthodox parishes along the newly reinforced Polish-Russian border on the Dnepr River at the time of Catherine II set the stage for the uprising. As Uniate religious practices had become more Latinized while Orthodoxy in this region drew ever closer into dependence on the Russian Orthodox Church, confessional tensions also reflected opposing Polish or Russian political allegiances. This article reaches beyond 
the context of Ukrainian national history to bring this event into current discourse on borderland regions and on overlapping political and religious identity.

\title{
Epidemic and Empire: Ethnicity, Class, and "Civilization" in the 1892 Tashkent Cholera Riot
}

\author{
JEFF SAHADEO
}

A cholera epidemic that swept through Central Asia on its way to Russia and Europe in 1892 transformed visions and practices of empire in Tashkent, the capital of the Russian province of Turkestan. Jeff Sahadeo argues that the epidemic revealed interdependencies between Russian colonizers and the predominantly Muslim local population, even as it produced ethnic violence. Tsarist officials and Russian settlers ruthlessly suppressed a June 1892 protest against anticholera measures that violated principles of local culture, based on Islam. Central Asian and Russian elites sought accommodation to prevent further violence; poor Russians, meanwhile, received censure for their own opposition to anticholera regulations and violence during the riot. Hopes that anticholera measures based on new advances in medicine pioneered by Robert Koch would display the superiority of European "civilization" evaporated. Tsarist administrators and Russian elites saw in the behavior of Central Asians and poor Russians proof of their inherent backwardness. The city remained under emergency statute until 1917, with administrators convinced of the danger of a revolutionary coalition across ethnic lines.

\section{The Trap of Backwardness: Modernity, Temporality, and the Study of Eastern European Nationalism}

\section{MARIA TODOROVA}

This article focuses on the discourse of backwardness as an aspect of what has been recognized as the dominant trope in east European historiography until the end of the twentieth century, namely nationalism. Through a survey of east European historiographies, it demonstrates how different notions of temporality are employed. Eastern Europe as a whole and the particular problem of east European nationalism have been constituted as historical objects of study very much on the pattern of anthropological objects, through structural models of "timeless" theory and method and bracketing out time as a dimension of intercultural study. The article proposes a way to circumvent the trap of origins, which carries backwardness as its corollary, by introducing the idea of relative synchronicity within a longue durée framework. This allows the description of a period in terms of linear consecutive developments but also as a dialogical process without overlooking important aspects of short-term historical analysis involving sequential development, transmission, and diffusion. 